\title{
Dehydrogenative Coupling of Primary Alcohols To Form Esters Catalyzed by a Ruthenium N-Heterocyclic Carbene Complex
}

\author{
Sølvhøj, Amanda Birgitte; Madsen, Robert
}

Published in:

Organometallics

Link to article, DOI:

10.1021/om200928b

Publication date:

2011

Document Version

Publisher's PDF, also known as Version of record

Link back to DTU Orbit

Citation (APA):

Sølvhøj, A. B., \& Madsen, R. (2011). Dehydrogenative Coupling of Primary Alcohols To Form Esters Catalyzed by a Ruthenium N-Heterocyclic Carbene Complex. Organometallics, 30, 6044-6048.

https://doi.org/10.1021/om200928b

\section{General rights}

Copyright and moral rights for the publications made accessible in the public portal are retained by the authors and/or other copyright owners and it is a condition of accessing publications that users recognise and abide by the legal requirements associated with these rights.

- Users may download and print one copy of any publication from the public portal for the purpose of private study or research.

- You may not further distribute the material or use it for any profit-making activity or commercial gain

- You may freely distribute the URL identifying the publication in the public portal 


\title{
Dehydrogenative Coupling of Primary Alcohols To Form Esters Catalyzed by a Ruthenium N-Heterocyclic Carbene Complex
}

\author{
Amanda Sølvhøj and Robert Madsen* \\ Department of Chemistry, Technical University of Denmark, DK-2800 Lyngby, Denmark
}

Supporting Information

ABSTRACT: The ruthenium complex $\left[\mathrm{RuCl}_{2}(\mathrm{I} i \mathrm{Pr})(p\right.$-cymene)] catalyzes the direct condensation of primary alcohols into esters and lactones with the release of hydrogen gas. The reaction is most effective with linear aliphatic alcohols and 1,4diols and is believed to proceed with a ruthenium dihydride as the catalytically active species.

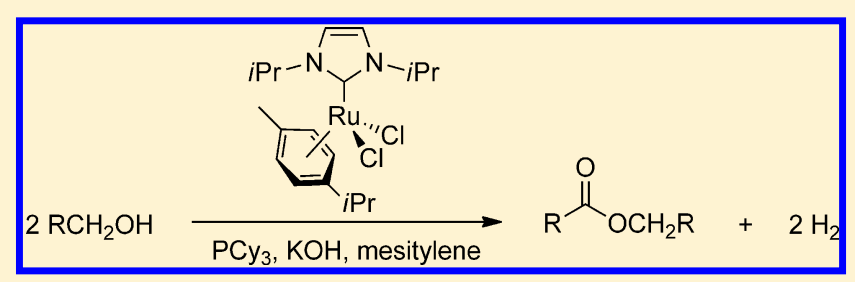

\section{INTRODUCTION}

$\mathrm{T}$ he synthesis of an ester is one of the most fundamental transformations in organic chemistry. The reaction is usually performed by coupling of a carboxylic acid or a derivative of a carboxylic acid with an alcohol. ${ }^{1}$ Although high yields can be obtained, the need for activation of the acid often leads to the formation of a significant amount of waste. As a result, other starting materials have been investigated for the development of more atom-economical esterifications. Aldehydes in the presence of alcohols can be oxidized directly to esters under aerobic conditions with a homogeneous NHC/ iron catalyst ${ }^{2}$ or heterogeneous gold catalysts. ${ }^{3}$ More significantly, primary alcohols can also be employed as starting materials for the direct aerobic oxidation to esters. The oxidation can be accomplished with homogeneous iridium ${ }^{4}$ and palladium $^{5}$ catalysts or with heterogeneous gold catalysts. ${ }^{6}$ A different approach to the oxidation can be used under anaerobic conditions where ester formation is achieved by dehydrogenation of the alcohol. This transformation can be catalyzed by ruthenium, ${ }^{7}$ iridium, ${ }^{8}$ and rhodium ${ }^{9}$ complexes, and the liberated hydrogen gas can be released from the reaction mixture or trapped with a stoichiometric scavenger such as a ketone or an olefin. The most attractive protocol is to perform the ester synthesis directly from a primary alcohol in the absence of a scavenger or an oxidant. This has so far been achieved with ruthenium $\mathrm{CNN}^{7 \mathrm{a}}$ and $\mathrm{PNN}$ pincer complexes, ${ }^{7 \mathrm{c}, \mathrm{d}} \mathrm{RuH}_{2}\left(\mathrm{PPh}_{3}\right)_{4}{ }^{7 \mathrm{e}}$ the Shvo catalyst, ${ }^{7 \mathrm{f}}$ and an iridium PCP pincer complex. ${ }^{8 \mathrm{a}}$ In addition, the special substrate butane-1,4diol has been converted into $\gamma$-butyrolactone and hydrogen gas with homogeneous ruthenium catalysts ${ }^{10}$ and heterogeneous copper catalysts. ${ }^{11}$

Recently, we have described a new dehydrogenative reaction for the synthesis of amides from primary alcohols and amines. ${ }^{12,13}$ The amidation was catalyzed by the ruthenium NHC complex 1 (Figure 1) in the presence of $\mathrm{PCy}_{3}$ and $\mathrm{KO} t \mathrm{Bu} .{ }^{12}$ With less reactive amines, some self-condensation of the primary alcohol into the corresponding ester was observed

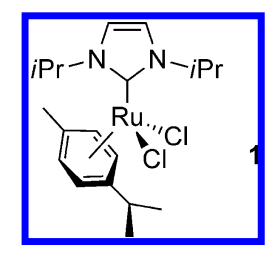

Figure 1. Structure of ruthenium NHC complex $\mathbf{1}$.

as a byproduct, and we speculated about whether the conditions could be modified into a dehydrogenative ester synthesis. Herein, we describe a new ruthenium-catalyzed synthesis of esters from primary alcohols in which hydrogen gas is liberated.

\section{RESULTS AND DISCUSSION}

For the initial studies, pentan-1-ol was selected as the test substrate and the reaction was performed in refluxing mesitylene under an argon atmosphere with $2.5 \%$ 1. It was quickly realized that a base was essential for ester formation because almost no conversion occurred under neutral conditions (Table 1 , entry 1 ). With $\mathrm{KO} t \mathrm{Bu}$, the yield of the ester increased when an increasing amount of the base was employed until a $58 \%$ yield was achieved with $20 \% \mathrm{KO} t \mathrm{Bu}$ (entries 2-6). Improved conversion was observed when a ligand such as $\mathrm{PCy}_{3}$ was also added, where the best result was obtained with $10 \% \mathrm{KO} t \mathrm{Bu}$ and $2.5 \% \mathrm{PCy}_{3}$ (entries 7-9). A number of other bases were also tested, and $\mathrm{KOH}$ proved to be a better choice than $\mathrm{KO} t \mathrm{Bu}$ for the esterification (entries 1015). Under these conditions, the $92 \%$ yield of pentyl pentanoate was obtained with $10 \% \mathrm{KOH}$ and $2.5 \% \mathrm{PCy}_{3}$ (entry 15). Other phosphine and amine ligands did not improve this result, and only tricyclopentylphosphine ( $\left.\mathrm{PCyp}_{3}\right)$ gave a comparable yield (entries 16-19). Varying the amount of $\mathrm{PCy}_{3}$ from 2.5 to $9 \%$ showed that a near-quantitative yield

Received: October 4, 2011

Published: October 14, 2011 
Table 1. Synthesis of Pentyl Pentanoate from Pentan-1-ol

\begin{tabular}{|c|c|c|c|c|c|}
\hline & $\mathrm{OH}$ & $\begin{array}{l}\stackrel{\% 1}{1} 1 \\
\text { ligand } \\
\text { ityene } \\
\text { C. } 18 \mathrm{~h}\end{array}$ & & & $+\mathrm{H}$ \\
\hline entry & base & $\%$ base & ligand & $\%$ ligand & yield $(\%)^{a}$ \\
\hline 1 & - & - & $\mathrm{PCy}_{3}$ & 2.5 & 1 \\
\hline 2 & $\mathrm{KO} t \mathrm{Bu}$ & 7.5 & - & - & 19 \\
\hline 3 & $\mathrm{KO} t \mathrm{Bu}$ & 10 & - & - & 26 \\
\hline 4 & $\mathrm{KO} t \mathrm{Bu}$ & 15 & - & - & 50 \\
\hline 5 & $\mathrm{KO} t \mathrm{Bu}$ & 20 & - & - & 58 \\
\hline 6 & $\mathrm{KO} t \mathrm{Bu}$ & 28 & - & - & 51 \\
\hline 7 & $\mathrm{KO} t \mathrm{Bu}$ & 20 & $\mathrm{PCy}_{3}$ & 2.5 & 32 \\
\hline 8 & $\mathrm{KO} t \mathrm{Bu}$ & 10 & $\mathrm{PCy}_{3}$ & 2.5 & 70 \\
\hline 9 & $\mathrm{KO} t \mathrm{Bu}$ & 7.5 & $\mathrm{PCy}_{3}$ & 2.5 & 52 \\
\hline 10 & $\mathrm{Et}_{3} \mathrm{~N}$ & 10 & $\mathrm{PCy}_{3}$ & 2.5 & 7 \\
\hline 11 & $\mathrm{NaHCO}_{3}$ & 10 & $\mathrm{PCy}_{3}$ & 2.5 & 68 \\
\hline 12 & $\mathrm{Na}_{2} \mathrm{CO}_{3}$ & 10 & $\mathrm{PCy}_{3}$ & 2.5 & 56 \\
\hline 13 & $\mathrm{~K}_{2} \mathrm{CO}_{3}$ & 10 & $\mathrm{PCy}_{3}$ & 2.5 & 71 \\
\hline 14 & $\mathrm{NaOH}$ & 10 & $\mathrm{PCy}_{3}$ & 2.5 & 81 \\
\hline 15 & $\mathrm{KOH}$ & 10 & $\mathrm{PCy}_{3}$ & 2.5 & 92 \\
\hline 16 & $\mathrm{KOH}$ & 10 & $\mathrm{PPh}_{3}$ & 2.5 & 66 \\
\hline 17 & $\mathrm{KOH}$ & 10 & $\mathrm{P}_{t} \mathrm{Bu}_{3}$ & 2.5 & 48 \\
\hline 18 & $\mathrm{KOH}$ & 10 & $\mathrm{PCyp}_{3}$ & 2.5 & 90 \\
\hline 19 & $\mathrm{KOH}$ & 10 & DABCO & 5 & 11 \\
\hline 20 & $\mathrm{KOH}$ & 10 & $\mathrm{PCy}_{3}$ & 4.5 & 97 \\
\hline 21 & $\mathrm{KOH}$ & 10 & $\mathrm{PCy}_{3}$ & 9 & 89 \\
\hline $22^{b}$ & $\mathrm{KOH}$ & 10 & $\mathrm{PCy}_{3}$ & 4.5 & 90 \\
\hline $23^{c}$ & $\mathrm{KOH}$ & 10 & $\mathrm{PCy}_{3}$ & 4.5 & 16 \\
\hline
\end{tabular}

could be achieved with a slight excess of the phosphine as compared to the ruthenium complex (entries 20 and 21). The corresponding methyl-substituted carbene complex $\left[\mathrm{RuCl}_{2}(\mathrm{IMe})(p\right.$-cymene) $]$ was also investigated, but a slightly lower yield was obtained in this case as compared to the yield with isopropyl complex 1 (entries 20 and 22). The importance of the carbene ligand was underlined by an experiment with the complex $\left[\mathrm{RuCl}_{2}(p \text {-cymene })\right]_{2}$ where an only $16 \%$ yield of pentyl pentanoate was observed (entry 23). Thus, the optimal catalyst system for general use consists of complex 1 together with $\mathrm{KOH}$ and $\mathrm{PCy}_{3}$ in refluxing mesitylene. Attempts to lower the reaction temperature by using a lower-boiling point solvent were not successful because reactions in toluene gave significantly lower yields while reactions in xylene were difficult to reproduce, although comparable yields were obtained in some cases. Experiments under neat conditions in the absence of a solvent also gave a lower yield because of the formation of several byproducts that were not further identified. The evolution of hydrogen during the reaction was confirmed by repeating the experiment in entry 20 with $1 \mathrm{mmol}$ of pentan-1ol. The reaction flask was connected to a measuring cylinder, and $17.5 \mathrm{~mL}$ was collected after $23 \mathrm{~h}$. This corresponds to 0.73 $\mathrm{mmol}$, and the gas was shown to be dihydrogen by using it for hydrogenating an alkyne in a separate experiment.

With the optimized catalyst system in place, our attention then shifted to other alcohols to investigate the scope of the dehydrogenative homodimerization (Table 2). Long chain aliphatic alcohols gave yields similar to those of pentan-1-ol (entries 1-3), whereas the yields with branched alcohols were somewhat lower (entries 4 and 5). The reaction with 2 -
Table 2. Synthesis of Esters and Lactones from Alcohols and Diols

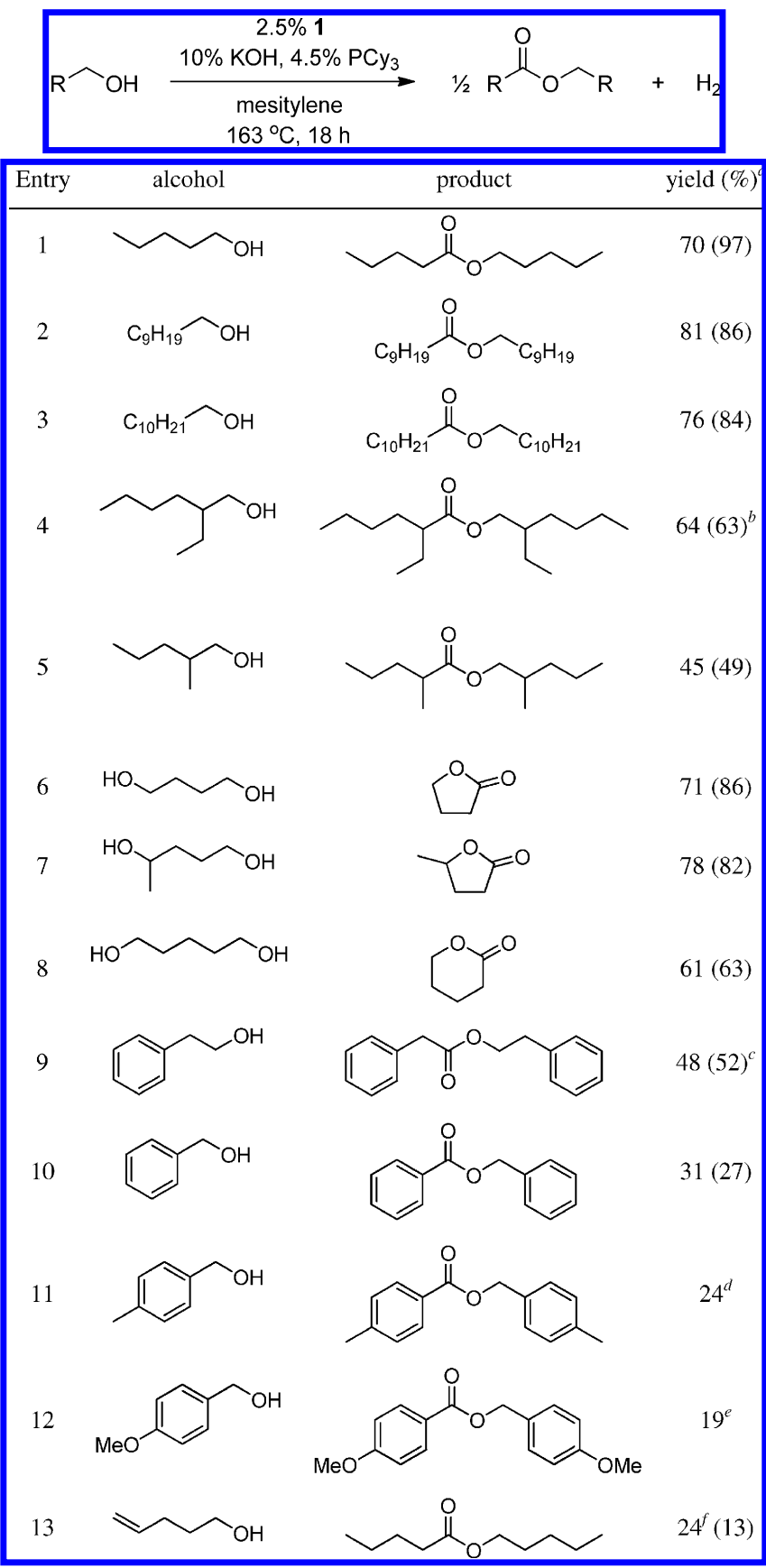

${ }^{a}$ Isolated yield (GC yield in parentheses). ${ }^{b}$ Heptane $(\sim 3 \%)$ was also formed. ${ }^{c}$ Toluene $(7 \%)$ was also formed. ${ }^{d}$ Toluene $(63 \%)$ was also formed. ${ }^{e}$ Anisole $(48 \%)$ was also formed. ${ }^{f}$ Inseparable mixture of saturated and unsaturated ester.

ethylhexan-1-ol in entry 4 was monitored over time, and the ester formed at the same rate as with pentan-1-ol in entry 1 . However, a small amount of heptane $(\sim 3 \%)$ was observed as a byproduct, indicating that a competing decarbonylation ${ }^{14}$ of the intermediate aldehyde is occurring with the branched alcohols. Lactonization of diols proceeded well under the esterification conditions as long as $\gamma$ - and $\delta$-lactones were formed (entries 68 ). The reaction in entry 6 was repeated under neat conditions with $1.25 \% 1$ and gave a $60 \%$ isolated yield of $\gamma$-butyrolactone. Other lactone sizes, however, did not form easily under the 
conditions described in Table 2. Propane-1,3-diol afforded no $\beta$-propiolactone, while hexane-1,6-diol gave traces of $\varepsilon$ caprolactone; in both cases, large amounts of the starting diols did not react. 2-Phenylethanol gave the ester in $48 \%$ isolated yield together with a small amount of toluene (entry 9). Benzylic alcohols, however, gave very low yields of the corresponding benzoates (entries 10-12). Surprisingly, the decarbonylation turned out to be the major reaction in these cases. This limits the substrate scope to saturated alcohols because alcohols containing olefins are partially reduced by the liberated hydrogen (entry 13).

Attempts to couple two different alcohols were not successful. The reaction between ethanol and pentan-1-ol gave roughly a statistical mixture of all four possible ester products. It was subsequently shown that transesterification with primary alcohols occurs readily under the reaction conditions, which may further contribute to the poor selectivity in the cross esterification. The reaction between pentan-1-ol and benzyl alcohol also resulted in a mixture of all four ester products. When pentan-1-ol was reacted with propan-2-ol, 2methylpropan-2-ol, or phenol, the only product was pentyl pentanoate from self-coupling of the primary alcohol and no cross esterification occurred with the secondary or tertiary alcohol or the phenol.

Several experiments were performed with special substrates to gain more information about the mechanism for the dehydrogenative esterification. When benzaldehyde was submitted to the standard conditions described in Table 2, the reaction gave only trace amounts of benzyl benzoate and benzyl alcohol. This rules out an aldehyde disproportionation mechanism, i.e., a Tishchenko reaction, ${ }^{15}$ as the main pathway for ester formation. The same result was obtained with $p$ methoxybenzaldehyde where trace amounts of anisole were also formed. Because anisole was the main product in entry 12 of Table 2, this experiment suggests that decarbonylation does not happen directly from an aldehyde in solution, but rather from an aldehyde generated on ruthenium. When a 1:1 mixture of $p$ methylbenzaldehyde and benzyl alcohol was reacted under the standard conditions, an evenly distributed mixture of all four esters was observed together with $p$-methylbenzyl alcohol. Following the reaction over time showed that the four esters were formed at approximately the same rate and a relatively large amount of $p$-methylbenzyl alcohol was formed rather quickly. This indicates that the hydrogen gas liberated at the beginning of the reaction was used for reduction of $p$ methylbenzaldehyde and the alcohol then entered the catalytic cycle. On the basis of these experiments and the fact that aldehydes are not observed as byproducts in Table 2, we believe the ester is formed from the alcohol by a pathway that does not involve a free aldehyde in solution.

An experiment was also conducted with benzyl alcohol- $\alpha, \alpha$ $d_{2}$ to investigate a possible exchange of deuterium and hydrogen during the reaction. Interestingly, when the reaction was performed as described in entry 10 of Table 2, benzyl benzoate was obtained with $64 \%$ hydrogen and $36 \%$ deuterium in the benzylic position as judged by ${ }^{1} \mathrm{H}$ NMR. The experiment was conducted in mesitylene- $d_{12}$, and the hydrogen incorporation is therefore not a result of an exchange with the solvent. When the same esterification was stopped after $2.5 \mathrm{~h}$ and the starting alcohol reisolated, it turned out that complete scrambling of hydrogen and deuterium had occurred in the $\alpha$-position. These experiments indicate that the initial $\beta$-hydride elimination to form benzaldehyde is a reversible reaction and, more significantly, that the catalytically active species is a ruthenium dihydride.

On the basis of these results and our previous studies of amidation, $^{12 a}$ we propose the esterification mechanism in Scheme 1 . Initially, the $p$-cymene ligand is lost, and the two

Scheme 1. Proposed Mechanism for Esterification

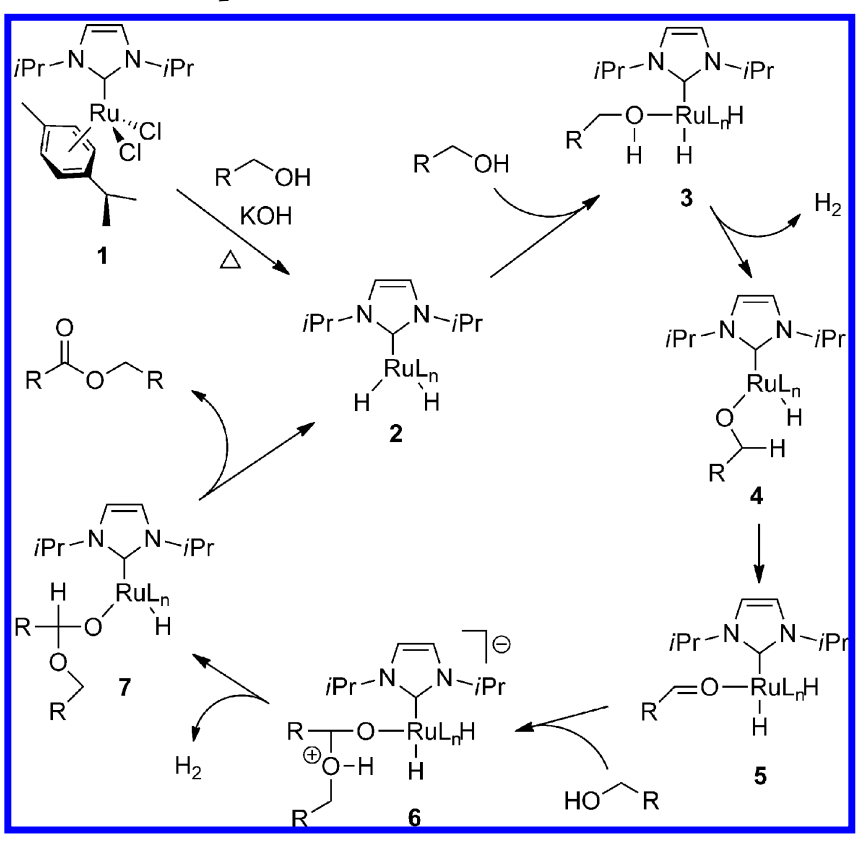

chloride ligands are replaced with hydride through alkoxide substitution and $\beta$-hydride elimination. The introduction of hydrides in this way has been shown earlier for other ruthenium(II) chloride complexes. ${ }^{16}$ This generates ruthenium dihydride 2 , which is believed to be the catalytically active species. Coordination of the alcohol affords complex 3, from which hydrogen gas is liberated by transfer of hydrogen to hydride as demonstrated previously. ${ }^{17}$ This furnishes complex 4, which upon $\beta$-hydride elimination yields aldehyde complex 5 where the carbonyl group can be $\sigma$ - or $\pi$-coordinated to ruthenium. ${ }^{18}$ Nucleophilic attack of the second molecule of alcohol then gives hemiacetal complex 6 . Transfer of hydrogen to hydride liberates the second molecule of hydrogen to give complex 7 , from which $\beta$-hydride elimination releases the ester product and regenerates active complex 2 . The scrambling of hydrogen and deuterium observed above can be explained by the fact that ruthenium dihydride complexes are known to scramble hydrogen and deuterium when subjected to hydrogen/deuterium gas. ${ }^{19}$ Combined with a reversible $\beta$-hydride elimination, this provides a pathway by which $\mathrm{OH}$ group hydrogens can be transferred into the $\alpha$-position of the alcohol.

In conclusion, we have described a new procedure for the dehydrogenative synthesis of esters from primary alcohols. The reaction is catalyzed by ruthenium NHC complex $\mathbf{1}$ and works most efficiently with linear aliphatic alcohols and 1,4-diols. A mechanism is proposed with a ruthenium dihydride species as the catalytically active component.

\section{EXPERIMENTAL SECTION}

General Information. All solvents were of HPLC grade and were not further purified. Column chromatography was performed on silica gel $(0.015-0.040 \mathrm{~mm})$. NMR chemical shifts were measured relative to the signals of residual $\mathrm{CHCl}_{3}\left(\delta_{\mathrm{H}} 7.26\right)$ and $\mathrm{CDCl}_{3}\left(\delta_{\mathrm{C}} 77.16\right)$. 
General Procedure for Ruthenium-Catalyzed Ester Formation. $\left[\mathrm{RuCl}_{2}(\mathrm{I} i \mathrm{Pr})(p \text {-cymene })\right]^{12 \mathrm{a}}(11.5 \mathrm{mg}, 0.025 \mathrm{mmol}), \mathrm{PCy}_{3}$ $(12.6 \mathrm{mg}, 0.045 \mathrm{mmol})$, and $\mathrm{KOH}(5.6 \mathrm{mg}, 0.1 \mathrm{mmol})$ were placed in an oven-dried Schlenk flask. The flask was evacuated and refilled with argon three times. The primary alcohol $(1 \mathrm{mmol} ; 0.5 \mathrm{mmol}$ in the case of a diol) in anhydrous mesitylene $(1 \mathrm{~mL})$ was added and the reaction mixture refluxed for $18 \mathrm{~h}$ under an argon atmosphere. The mixture was cooled to room temperature and purified directly by dry column vacuum chromatography ${ }^{20}$ (DCVC).

Pentyl Pentanoate. DCVC eluting with pentane containing 2\% increments of ethyl acetate per fraction gave the product as a slightly yellow oil: ${ }^{1} \mathrm{H}$ NMR $\left(300 \mathrm{MHz}, \mathrm{CDCl}_{3}\right) \delta 3.92(\mathrm{t}, J=6.7 \mathrm{~Hz}, 2 \mathrm{H})$, $2.16(\mathrm{t}, J=7.5 \mathrm{~Hz}, 2 \mathrm{H}), 1.62-1.40(\mathrm{~m}, 4 \mathrm{H}), 1.32-1.11(\mathrm{~m}, 6 \mathrm{H})$, $0.91-0.70(\mathrm{~m}, 6 \mathrm{H}) ;{ }^{13} \mathrm{C}$ NMR $\left(75 \mathrm{MHz}, \mathrm{CDCl}_{3}\right) \delta 174.0,64.4,34.2$, 28.4, 28.2, 27.2, 22.4, 22.4, 14.0, 13.8; MS $m / z 173[\mathrm{M}+\mathrm{H}]^{+}$. NMR data are in accord with literature values. ${ }^{21}$

Decyl Decanoate. DCVC eluting with heptane containing $2 \%$ increments of ethyl acetate per fraction gave the product as a slightly yellow oil: ${ }^{1} \mathrm{H}$ NMR $\left(300 \mathrm{MHz}, \mathrm{CDCl}_{3}\right) \delta 4.04(\mathrm{t}, J=6.7 \mathrm{~Hz}, 2 \mathrm{H})$, $2.27(\mathrm{t}, J=7.5 \mathrm{~Hz}, 2 \mathrm{H}), 1.66-1.53(\mathrm{~m}, 4 \mathrm{H}), 1.25(\mathrm{~m}, 26 \mathrm{H}), 0.86(\mathrm{t}, J$ $=6.6 \mathrm{~Hz}, 6 \mathrm{H}) ;{ }^{13} \mathrm{C} \mathrm{NMR}\left(75 \mathrm{MHz}, \mathrm{CDCl}_{3}\right) \delta 174.1,64.5,34.5,32.0$, $32.0,29.7,29.7,29.6,29.5,29.4,29.4,29.4,29.3,28.8,26.1,25.2,22.8$, $22.8,14.2,14.2$; MS $m / z 312[\mathrm{M}]^{+}$. NMR data are in accord with literature values. ${ }^{22}$

Undecyl Undecanoate. DCVC eluting with heptane containing $2 \%$ increments of ethyl acetate per fraction gave the product as a slightly yellow oil: ${ }^{1} \mathrm{H}$ NMR $\left(300 \mathrm{MHz}, \mathrm{CDCl}_{3}\right) \delta 4.04(\mathrm{t}, J=6.7 \mathrm{~Hz}$, $2 \mathrm{H}), 2.27(\mathrm{t}, J=7.5 \mathrm{~Hz}, 2 \mathrm{H}), 1.69-1.50(\mathrm{~m}, 4 \mathrm{H}), 1.25(\mathrm{bs}, 30 \mathrm{H}), 0.86$ $(\mathrm{t}, J=6.6 \mathrm{~Hz}, 6 \mathrm{H}) ;{ }^{13} \mathrm{C}$ NMR $\left(75 \mathrm{MHz}, \mathrm{CDCl}_{3}\right) \delta 174.1,64.5,34.5$, $32.0,29.8,29.7,29.7,29.7,29.6,29.5,29.5,29.4,29.4,29.3,28.8,26.1$, 25.2, 22.8, 14.2, 14.2; MS $m / z 340[\mathrm{M}]^{+}$. NMR data are in accord with literature values. ${ }^{23}$

2-Ethylhexyl 2-Ethylhexanoate. DCVC eluting with pentane containing $2 \%$ increments of ethyl acetate per fraction gave the product as a slightly yellow oil: ${ }^{1} \mathrm{H}$ NMR $\left(300 \mathrm{MHz}, \mathrm{CDCl}_{3}\right) \delta 3.97$ $(\mathrm{d}, J=5.7 \mathrm{~Hz}, 2 \mathrm{H}), 2.31-2.17(\mathrm{~m}, 1 \mathrm{H}), 1.64-1.10(\mathrm{~m}, 17 \mathrm{H}), 0.95-$ $0.69(\mathrm{~m}, 12 \mathrm{H}) ;{ }^{13} \mathrm{C} \mathrm{NMR}\left(75 \mathrm{MHz}, \mathrm{CDCl}_{3}\right) \delta 176.7,66.3,47.7,38.9$, 32.0, 30.6, 29.8, 29.0, 25.7, 24.0, 23.1, 22.8, 14.1, 14.0, 12.0, 11.1; MS $\mathrm{m} / z 257[\mathrm{M}+\mathrm{H}]^{+}$. NMR data are in accord with literature values. ${ }^{23}$

2-Methylpentyl 2-Methylpentanoate. DCVC eluting with pentane containing $2 \%$ increments of ethyl acetate per fraction gave the product as a slightly yellow oil: ${ }^{1} \mathrm{H}$ NMR $\left(300 \mathrm{MHz}, \mathrm{CDCl}_{3}\right) \delta 4.01-$ $3.88(\mathrm{~m}, 1 \mathrm{H}), 3.87-3.79(\mathrm{~m}, 1 \mathrm{H}), 2.42(\mathrm{dt}, J=13.8,7.0 \mathrm{~Hz}, 1 \mathrm{H})$, $1.86-1.70(\mathrm{~m}, 1 \mathrm{H}), 1.70-1.55(\mathrm{~m}, 1 \mathrm{H}), 1.44-1.20(\mathrm{~m}, 7 \mathrm{H}), 1.12(\mathrm{~d}$, $J=7.0 \mathrm{~Hz}, 3 \mathrm{H}), 0.95-0.79(\mathrm{~m}, 9 \mathrm{H}) ;{ }^{13} \mathrm{C} \mathrm{NMR}\left(75 \mathrm{MHz}, \mathrm{CDCl}_{3}\right) \delta$ 177.1, 69.2, 39.6, 39.6, 36.1, 35.7, 32.4, 20.5, 20.0, 17.2, 17.0, 17.0, 14.4, 14.1; MS $\mathrm{m} / z 201[\mathrm{M}+\mathrm{H}]^{+}$. NMR data are in accord with literature values. ${ }^{24}$

$\gamma$-Butyrolactone. DCVC eluting with heptane containing $10 \%$ increments of ethyl acetate per fraction gave the product as a colorless oil: ${ }^{1} \mathrm{H}$ NMR $\left(300 \mathrm{MHz}, \mathrm{CDCl}_{3}\right) \delta 4.31(\mathrm{t}, J=7.0 \mathrm{~Hz}, 2 \mathrm{H}), 2.50-$ $2.41(\mathrm{~m}, 2 \mathrm{H}), 2.29-2.17(\mathrm{~m}, 2 \mathrm{H}) ;{ }^{13} \mathrm{C}$ NMR $\left(75 \mathrm{MHz}, \mathrm{CDCl}_{3}\right) \delta$ $177.8,68.6,27.8,22.2 ; \mathrm{MS} m / z 86[\mathrm{M}]^{+}$. NMR data are in accord with literature values. ${ }^{25}$

$\gamma$-Valerolactone. DCVC eluting with heptane containing $10 \%$ increments of ethyl acetate per fraction gave the product as a colorless oil: ${ }^{1} \mathrm{H}$ NMR $\left(300 \mathrm{MHz}, \mathrm{CDCl}_{3}\right) \delta 4.62-4.50(\mathrm{~m}, 1 \mathrm{H}), 2.50-2.43$ $(\mathrm{m}, 2 \mathrm{H}), 2.35-2.23(\mathrm{~m}, 1 \mathrm{H}), 1.82-1.68(\mathrm{~m}, 1 \mathrm{H}), 1.32(\mathrm{~d}, J=6.2 \mathrm{~Hz}$, $3 \mathrm{H}) ;{ }^{13} \mathrm{C}$ NMR (75 MHz, $\mathrm{CDCl}_{3}$ ) $\delta 177.2,77.2,29.6,29.0,21.0$; MS $\mathrm{m} / z 100[\mathrm{M}]^{+}$. NMR data are in accord with literature values. ${ }^{25}$

$\delta$-Valerolactone. DCVC eluting with heptane containing $10 \%$ increments of ethyl acetate per fraction gave the product as a colorless oil: ${ }^{1} \mathrm{H}$ NMR $\left(300 \mathrm{MHz}, \mathrm{CDCl}_{3}\right) \delta 4.21(\mathrm{t}, J=5.9 \mathrm{~Hz}, 2 \mathrm{H}), 2.42(\mathrm{t}, J$ $=7.0 \mathrm{~Hz}, 2 \mathrm{H}), 1.88-1.65(\mathrm{~m}, 4 \mathrm{H}) ;{ }^{13} \mathrm{C}$ NMR $\left(75 \mathrm{MHz}, \mathrm{CDCl}_{3}\right) \delta$ $171.3,69.3,29.6,22.1,18.8$; MS $m / z 100[\mathrm{M}]^{+}$. NMR data are in accord with literature values. ${ }^{25}$

Phenethyl 2-Phenylacetate. DCVC eluting with heptane containing $2 \%$ increments of ethyl acetate per fraction gave the product as a slightly yellow oil: ${ }^{1} \mathrm{H}$ NMR $\left(300 \mathrm{MHz}, \mathrm{CDCl}_{3}\right) \delta 7.45-7.16(\mathrm{~m}$, $10 \mathrm{H}), 4.36(\mathrm{t}, J=7.0 \mathrm{~Hz}, 2 \mathrm{H}), 3.65(\mathrm{~s}, 2 \mathrm{H}), 2.96(\mathrm{t}, J=7.0 \mathrm{~Hz}, 2 \mathrm{H})$;
${ }^{13} \mathrm{C} \mathrm{NMR}\left(75 \mathrm{MHz}, \mathrm{CDCl}_{3}\right) \delta 171.6,137.8,134.1,129.4,129.0,128.6$, $128.5,127.1,126.6,65.4,41.5,35.1 ; \mathrm{MS} m / z 104\left[\mathrm{C}_{8} \mathrm{H}_{8}\right]^{+}$. NMR data are in accord with literature values. ${ }^{12 a}$

Benzyl Benzoate. DCVC eluting with heptane containing 2\% increments of ethyl acetate per fraction gave the product as a slightly yellow oil: ${ }^{1} \mathrm{H}$ NMR $\left(300 \mathrm{MHz}, \mathrm{CDCl}_{3}\right) \delta 8.16-8.09(\mathrm{~m}, 2 \mathrm{H}), 7.61-$ $7.54(\mathrm{~m}, 1 \mathrm{H}), 7.52-7.33(\mathrm{~m}, 7 \mathrm{H}), 5.40(\mathrm{~s}, 2 \mathrm{H}) ;{ }^{13} \mathrm{C} \mathrm{NMR}(75 \mathrm{MHz}$, $\left.\mathrm{CDCl}_{3}\right) \delta 166.5,136.1,133.1,130.2,129.8,128.7,128.4,128.3,128.2$, $66.7 ; \mathrm{MS} m / z 212[\mathrm{M}]^{+}$. NMR data are in accord with literature values. $^{26}$

4-Methylbenzyl 4-Methylbenzoate. DCVC eluting with heptane containing $2 \%$ increments of ethyl acetate per fraction gave the product as a slightly yellow oil: ${ }^{1} \mathrm{H}$ NMR $\left(300 \mathrm{MHz}, \mathrm{CDCl}_{3}\right) \delta 7.97$ $(\mathrm{d}, J=8.3 \mathrm{~Hz}, 2 \mathrm{H}), 7.35(\mathrm{~d}, J=8.0 \mathrm{~Hz}, 2 \mathrm{H}), 7.23(\mathrm{~d}, J=8.1 \mathrm{~Hz}, 2 \mathrm{H})$, $7.20(\mathrm{~d}, J=8.4 \mathrm{~Hz}, 2 \mathrm{H}), 5.32(\mathrm{~s}, 2 \mathrm{H}), 2.41(\mathrm{~s}, 3 \mathrm{H}), 2.37(\mathrm{~s}, 3 \mathrm{H}) ;{ }^{13} \mathrm{C}$ NMR $\left(75 \mathrm{MHz}, \mathrm{CDCl}_{3}\right) \delta 166.7,143.8,138.1,133.3,129.8,129.4$, $129.2,128.4,127.6,66.6,21.8,21.3 ; \mathrm{MS} m / z 240[\mathrm{M}]^{+}$. NMR data are in accord with literature values. ${ }^{8 a}$

4-Methoxybenzyl 4-Methoxybenzoate. DCVC eluting with heptane containing $2 \%$ increments of ethyl acetate per fraction gave the product as a slightly yellow oil: ${ }^{1} \mathrm{H}$ NMR $\left(300 \mathrm{MHz}, \mathrm{CDCl}_{3}\right) \delta 8.02$ $(\mathrm{d}, J=9.0 \mathrm{~Hz}, 2 \mathrm{H}), 7.39(\mathrm{~d}, J=8.8 \mathrm{~Hz}, 2 \mathrm{H}), 6.92(\mathrm{~d}, J=3.4 \mathrm{~Hz}, 2 \mathrm{H})$ $6.89(\mathrm{~d}, J=3.6 \mathrm{~Hz}, 2 \mathrm{H}), 5.27(\mathrm{~s}, 2 \mathrm{H}), 3.84(\mathrm{~s}, 3 \mathrm{H}), 3.81(\mathrm{~s}, 3 \mathrm{H}) ;{ }^{13} \mathrm{C}$ NMR $\left(75 \mathrm{MHz} \mathrm{CDCl}_{3}\right) \delta 166.4,163.5,159.7,131.8,130.1,128.5$, $122.8,114.0,113.7,66.4,55.5,55.4 ; \mathrm{MS} m / z 272[\mathrm{M}]^{+}$. NMR data are in accord with literature values. ${ }^{5 \mathrm{c}}$

\section{ASSOCIATED CONTENT}

\section{S Supporting Information}

${ }^{1} \mathrm{H}$ and ${ }^{13} \mathrm{C}$ NMR spectra. This material is available free of charge via the Internet at http://pubs.acs.org.

\section{AUTHOR INFORMATION}

\section{Corresponding Author}

*E-mail: rm@kemi.dtu.dk.

\section{ACKNOWLEDGMENTS}

We thank the Danish Council for Independent ResearchTechnology and Production Sciences for financial support.

\section{REFERENCES}

(1) Otera, J.; Nishikido, J. Esterification: Methods, Reactions, and Applications; Wiley-VCH: Weinheim, Germany, 2010.

(2) Reddy, R. S.; Rosa, J. N.; Veiros, L. F.; Caddick, S.; Gois, P. M. P. Org. Biomol. Chem. 2011, 9, 3126.

(3) (a) Yasukawa, T.; Miyamura, H.; Kobayashi, S. Chem. Asian J. 2011, 6, 621. (b) Marsden, C.; Taarning, E.; Hansen, D.; Johansen, L.; Klitgaard, S. K.; Egeblad, K.; Christensen, C. H. Green Chem. 2008, 10, 168.

(4) (a) Arita, S.; Koike, T.; Kayaki, Y.; Ikariya, T. Chem. Asian J. 2008, 3, 1479. (b) Izumi, A.; Obora, Y.; Sakaguchi, S.; Ishii, Y. Tetrahedron Lett. 2006, 47, 9199.

(5) (a) Luo, F.; Pan, C.; Cheng, J.; Chen, F. Tetrahedron 2011, 67, 5878. (b) Liu, C.; Wang, J.; Meng, L.; Deng, Y.; Li, Y.; Lei, A. Angew. Chem. Int. Ed. 2011, 50, 5144. (c) Gowrisankar, S.; Neumann, H.; Beller, M. Angew. Chem., Int. Ed. 2011, 50, 5139.

(6) (a) Kaizuka, K.; Miyamura, H.; Kobayashi, S. J. Am. Chem. Soc. 2010, 132, 15096. (b) Xu, B.; Haubrich, J.; Freyschlag, C. G.; Madix, R. J.; Friend, C. M. Chem. Sci. 2010, 1, 310. (c) Su, F.-Z.; Ni, J.; Sun, H.; Cao, Y.; He, H.-Y.; Fan, K.-N. Chem.-Eur. I. 2008, 14, 7131. (d) Nielsen, I. S.; Taarning, E.; Egeblad, K.; Madsen, R.; Christensen, C. H. Catal. Lett. 2007, 116, 35.

(7) (a) del Pozo, C.; Iglesias, M.; Sánchez, F. Organometallics 2011, 30, 2180. (b) Owston, N. A.; Nixon, T. D.; Parker, A. J.; Whittlesey, M. K.; Williams, J. M. J. Synthesis 2009, 1578. (c) Zhang, J.; Gandelman, M.; Shimon, L. J. W.; Milstein, D. Dalton Trans. 2007, 107. (d) Zhang, J.; Leitus, G.; Ben-David, Y.; Milstein, D. J. Am. Chem. 
Soc. 2005, 127, 10840. (e) Murahashi, S.-I.; Naota, T.; Ito, K.; Maeda, Y.; Taki, H. J. Org. Chem. 1987, 52, 4319. (f) Blum, Y.; Shvo, Y. J. Organomet. Chem. 1985, 282, C7.

(8) (a) Musa, S.; Shaposhnikov, I.; Cohen, S.; Gelman, D. Angew. Chem.. Int. Ed. 2011, 50, 3533. (b) Yamamoto, N.; Obora, Y.; Ishii, Y. L. Org. Chem. 2011, 76, 2937. (c) Suzuki, T.; Matsuo, T.; Watanabe, K.; Katoh, T. Synlett 2005, 1453.

(9) Zweifel, T.; Naubron, J.-V.; Grützmacher, H. Angew. Chem., Int. Ed. 2009, 48, 559.

(10) Zhao, J.; Hartwig, J. F. Organometallics 2005, 24, 2441.

(11) (a) Hwang, D. W.; Kashinathan, P.; Lee, J. M.; Lee, J. H.; Lee, U.-h.; Hwang, J.-S.; Hwang, Y. K.; Chang, J.-S. Green Chem. 2011, 13, 1672. (b) Mikami, Y.; Ebata, K.; Mitsudome, T.; Mizugaki, T.; Jitsukawa, K.; Kaneda, K. Heterocycles 2010, 80, 855. (c) Ichikawa, N.; Sato, S.; Takahashi, R.; Sodesawa, T.; Inui, K. I. Mol. Catal. A: Chem. 2004, 212, 197.

(12) (a) Dam, J. H.; Osztrovszky, G.; Nordstrøm, L. U.; Madsen, R. Chem.-Eur. J. 2010, 16, 6820. (b) Nordstrøm, L. U.; Vogt, H.; Madsen, R. I.Am. Chem. Soc. 2008, 130, 17672.

(13) See also: Chen, C.; Hong, S. H. Org. Biomol. Chem. 2011, 9, 20.

(14) Fristrup, P.; Kreis, M.; Palmelund, A.; Norrby, P.-O.; Madsen, R. J. Am. Chem. Soc. 2008, 130, 5206.

(15) Simon, M.-O.; Darses, S. Adv. Synth. Catal. 2010, 352, 305.

(16) (a) Solari, E.; Gauthier, S.; Scopelliti, R.; Severin, K. Organometallics 2009, 28, 4519. (b) Aranyos, A.; Csjernyik, G.; Szabo, K. J.; Bäckvall, J.-E. Chem. Commun. 1999, 351.

(17) Chatwin, S. L.; Davidson, M. G.; Doherty, C.; Donald, S. M.; Jazzar, R. F. R.; Macgregor, S. A.; McIntyre, G. J.; Mahon, M. F.; Whittlesey, M. K. Organometallics 2006, 25, 99.

(18) Bosson, J.; Poater, A.; Cavallo, L.; Nolan, S. P. J. Am. Chem. Soc. 2010, 132, 13146.

(19) Burling, S.; Kociok-Köhn, G.; Mahon, M. F.; Whittlesey, M. K.; Williams, J. M. J. Organometallics 2005, 24, 5868.

(20) Pedersen, D. S.; Rosenbohm, C. Synthesis 2001, 2431.

(21) Kapustina, N. I.; Sokova, L. L.; Makhaev, V. D.; Borisov, A. P.; Nikishin, G. I. Russ. Chem. Bull., Int. Ed. 2000, 49, 1842.

(22) Khusnutdinov, R. I.; Shchadneva, N. A.; Baiguzina, A. R.; Lavrentieva, Y. Y.; Dzhemilev, U. M. Russ. Chem. Bull., Int. Ed. 2002, 51,2074

(23) Nikishin, G. I.; Sokova, L. L.; Kapustina, N. I. Russ. Chem. Bull., Int. Ed. 2009, 58, 303.

(24) Morita, K.-I.; Nishiyama, Y.; Ishii, Y. Organometallics 1993, 12, 3748.

(25) Mitsudome, T.; Noujima, A.; Mizugaki, T.; Jitsukawa, K.; Kaneda, K. Green Chem. 2009, 11, 793.

(26) Hans, J. J.; Driver, R. W.; Burke, S. D. J. Org. Chem. 2000, 65, 2114 